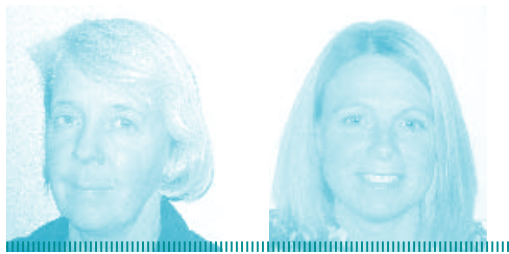

Janet Ververda, høyskolelektor HiT.
Anita Kornkåsa, sykepleier, hjemmetjenesten, Nome kommune.
Eva Kløw Bjørntvedt sykepleier, hjemmetjenesten.
FAG

Psykisk lidelse
Line Melby Egrem,

sykepleier, ortopedisk

avdeling, Sykehuset

Telemark HF.

\title{
Pasienter med schizofreni på sykehus
}

\author{
Sykepleiere på somatiske sykehus mangler ofte kunnskap og kompetanse for å ivareta pasienter med \\ schizofrenidiagnose.
}

$\mathbf{V}$ åre erfaringer fra somatiske sykehusavdelinger tilsier at å ivareta pasienter med psykisk sykdom i tillegg til somatisk sykdom kan være utfordrende. Gjennom sykepleierutdannelsen har vi sett betydningen av å ha et helhetlig menneskesyn for å kunne utføre tilfredsstillende sykepleie $(1,2)$. Med denne artikkelen ønsker vi å bidra med vår kunnskap om hvordan sykepleier kan møte denne pasientgruppen. Vi har intervjuet tre sykepleiere på to medisinske avdelinger og tilegnet oss kunnskap gjennom litteraturstudier. Vi brukte Travelbees teori når vi så på hvordan sykepleier kan ivareta en pasient med schizofreni i en somatisk sykehusavdeling

\section{Schizofreni}

Schizofreni regnes som den alvorligste blant psykiske lidelser. Det er til en hver tid cirka

\section{Hovedbudskap}

Artikkelen beskriver noen utfordringer sykepleiere møter når de skal ivareta schizofrene pasienter i en somatisk avdeling. Både forskning og informantene viser at forutinntatte oppfatninger kan føre til usikkerhet, redsel og negative holdninger. Det er viktig å øke kompetansen, men også at sykepleieren fokuserer på det hun kan framfor det hun ikke kan, for å oppnå en menneske-tilmenneske-relasjon mellom sykepleier og pasient.

\section{Søkeord}

Les mer og finn litteraturhenvisninger på våre nettsider. ) Psykiskhelse \Somatisklidelse /Psykose
20000 personer i Norge med denne diagnosen, som gir forstyrrelser i tenkning, persepsjon og følelsesliv. Videre kjennetegnes sykdommen av positive og negative symptomer. Positive symptomer er tydelige, synlige og dermed observerbare for andre. Dette innebærer hallusinasjoner, vrangforestillinger eller kaotisk atferd. Negative symptomer er mindre påfallende, men like alvorlig for personen som har dem. Disse kan arte seg som følelsesmessig avflating, viljeshemming, lite initiativ og engasjement, fravær av spontan tale, kontaktsvakhet og gledesløshet $(3,4)$.

\section{Dårlig helse}

Pasienter med schizofreni har generelt dårlig kroppslig helse, og mange mener at helsetjenesten ikke tar deres kroppslige plager på alvor. Pasientene dør også tidligere enn forventet på grunn av selvmord eller kroppslige sykdommer. Schizofreni er forbundet med helseskadelig atferd, som tobakksrøyking, dårlig kosthold, lite fysisk aktivitet og mangel på personlig hygiene. En del av pasientene har i tillegg et alvorlig rusmiddelproblem. Mange av pasientene vil også få betydelig vektøkning på grunn av medikamentell behandling. Mennesker med schizofreni er overrepresentert når det gjelder diabetes, lungesykdom, hjerte- og karlidelser og mage- og tarmsykdom. Årsaken til dette er sammensatt. De nevnte faktorene har stor betydning, i tillegg til at de ofte kommer seint til behandling for sine somatiske plager. Sykdommen kan derfor allerede være langtkommen. Pasienter med schizofreni blir ofte sett på som vanskelige, noe som oftest skyldes faktorer direkte relatert til diagnosen. Negative symptomer kan oppfattes som at pasienten er tiltaksløs eller lat, mens positive symptomer kan virke skremmende og være vanskelig å forholde seg til. Dette kan by på utfordringer i samhandlingen mellom sykepleier og pasient $(5,4)$.

\section{Sykepleieren er forutinntatt}

Sykepleiere er ofte forutinntatt om at pasienter med en psykisk diagnose vil være problematiske og kreve mer omsorg enn andre (5). Pasienter med schizofreni blir ansett for å være farlige og uforutsigbare av dem som arbeider $\mathrm{i}$ somatikken. For at sykepleieren skal kunne se mennesket i pasienten er det en forutsetning at sykepleieren har evne til å bryte ut av sine forutinntatte oppfatninger (6). Sykepleier blir også påvirket av ytre faktorer. En av våre informanter nevnte terrorhendelsen 22. juli 2011, hvor gjerningsmannen fikk diagnosen paranoid schizofreni. Hun uttalte at hun etter den omfattende dekningen av denne hadde utviklet en mer skeptisk holdning, noe hun mente hun ikke hadde i utgangspunktet. Helsepersonell som jobber ved somatiske sykehus mangler og savner kunnskap og kompetanse for å ivareta pasienter med schizofrenidiagnose, noe våre informanter bekrefter $(2,7,8)$. Vi spurte blant annet hvordan de opplevde en situasjon der de hadde ansvar for en pasient med diagnosen schizofreni. Den ene informanten svarte: «Det er vanskelig når en ikke har kompetanse på det. For en blir usikker på hvordan en skal gå frem, 


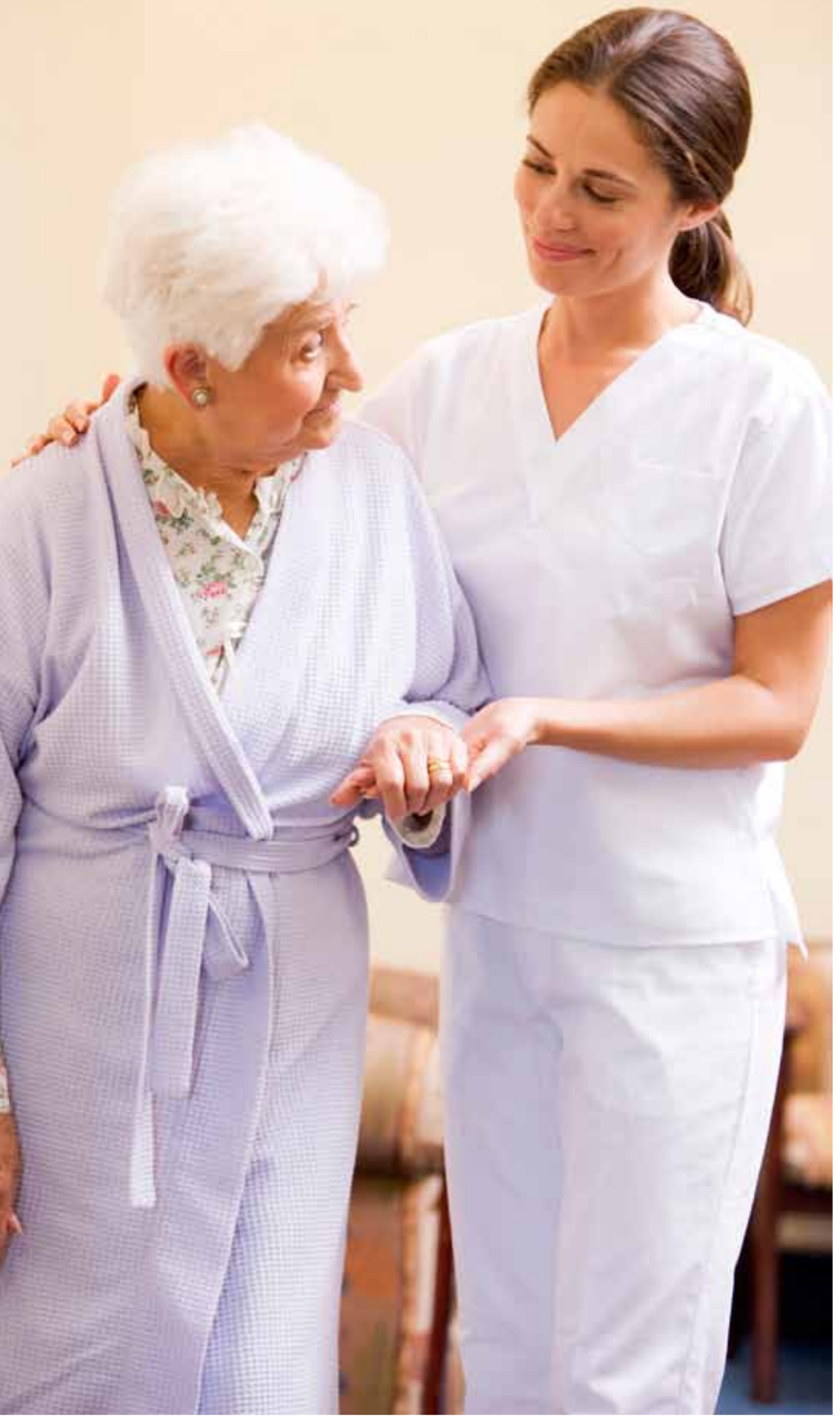

GJENSIDIG TILLIT: Å bygge opp et tillitsforhold til pasienter med schizofreni krever at sykepleieren er aktiv, tålmodig og aksepterende. Illustrasjonsfoto: Colourbox og jeg er redd for at han kan bli aggressiv». Våre to andre informanter hadde lignende utsagn. Slike kategoriseringer er en stor barriere som hindrer oss i å skape en relasjon og se mennesket som et unikt individ. Dette er en gjensidig prosess mellom sykepleier og pasient, men det vil alltid være sykepleiers ansvar å bryte ned kategoriseringen (6).

\section{Gode holdninger}

Selv om sykepleiere skårer høyt når det gjelder fordommer overfor pasienter med psykiske lidelser (2), stemte det ikke overens med våre funn. Sykepleierne i vårt prosjekt uttrykte gode holdninger til og stor omtanke for pasientene. De

\section{«Pasienter med schizofreni har generelt dårlig kroppslig helse.»}

uttalte at det ikke var diagnosen som bestemte hvordan de møtte den enkelte pasienten. De fortalte at det varierer mye hvor sterkt pasienten er preget av sykdommen sin. Dette viser at sykepleierne sitter inne med viktige erfaringer, som de bruker i møte med hver enkelt pasient, ikke kun pasienter med schizofreni.

Informantene synes det er vanskelig når pasienten er plaget med hallusinasjoner og vrangforestillinger. En informant uttalte «For oss som er friske er det merkelig å tenke på at noen har stemmer i hodet som sier at du skal gjøre ditt og 
datt». Hvis pasienten uttrykker angst og redsel på grunn av hallusinasjoner og vrangforestillinger, kan det være vanskelig for sykepleieren å sette seg inn i situasjonen. Sykepleieren må ønske å oppnå empati og deretter sympati, slik at hun kan bidra til å lindre den sykes lidelse. Sykepleierens egenart og bakgrunn vil virke inn på evnen til å føle empati med den andre. Dette kan være vanskelig da pasienten kan være svært forskjellig fra en selv, både med tanke på personlighet og atferd. Sykepleier må i disse tilfellene anerkjenne at pasienten er forskjellig fra henne

\section{«Sykepleier vil møte men- nesker med psykiske lidelser over alt.»)}

selv, for å kunne gå videre til sympatifasen. Vil sykepleieren åpne for en empatisk relasjon må hun tørre å stille seg selv i en sårbar posisjon. Sykepleier skal gi ubetinget pleie og omsorg og kan ikke forvente å få noe tilbake fra pasienten. Pasientene kan i perioder ha vanskelig for å forholde seg til andre enn seg selv. Dette må hun forholde seg profesjonelt til og ikke la det hindre den videre prosessen (6).

\section{Gjensidig forståelse}

På grunn av de negative symptomene kan pasienten være sosialt tilbaketrukket. Det kan derfor være lett for sykepleieren å tolke dette som at pasienten vil være i fred og ikke ønsker involvering fra andre. Slik kan det oppstå en situasjon hvor sykepleieren trekker seg unna, selv om pasienten har behov for oppmerksomhet og omsorg. Vi mener det er viktig at man oppretter et tillitsforhold så tidlig som mulig. Dette vil kreve at sykepleieren er aktiv, men tålmodig og har en aksepterende holdning. Det kan ta tid å bygge opp en allianse mellom pasient og sykepleier. Det er derfor en fordel både for pasient og sykepleier at det er kontinuitet $\mathrm{i}$ oppfølgingen av den enkelte pasient og at pasienten får mulighet til å forholde seg til færrest mulig sykepleiere. Dette kan trygge sykepleieren og bidra til å ivareta pasienter med schizofrenidiagnose bedre (9).

En sykepleier trodde at hun kunne miste pasientens tillit bare ved å si noe feil og dermed bli hindret i å gi den omsorgen hun ønsket. I de situasjonene hvor man opplever det som vanskelig å vite hva man skal si, er det ikke alltid nødvendig å si noe. Det beste er å være til stede i situasjonen og fungere som en «container». Dette innebærer å ta imot pasientens tankekaos, som kan komme ut som mer eller mindre sammenhengende ord og setninger. Videre ser vi det som sentralt at sykepleier er bevisst på kommunikasjon og kan bruke seg selv terapeutisk $(10,17,11)$.

\section{Kommunikasjon}

Å legge til rette for god kommunikasjon og et meningsfylt samspill er sykepleierens ansvar. Sykepleieren bør være lyttende og åpen for hva pasienten sier og gi klar og tydelig informasjon. Hun må ta hensyn til pasientens kognitive funksjon og hans kommunikasjonsevne. Tankeforstyrrelser og kognitiv svikt er faktorer som er med på å svekke forståelsen av informasjonen som blir gitt $(12,13)$. Fordi personer med schizofreni lettere lar seg distrahere enn andre, vil man ikke alltid oppnå blikkontakt. Dette kan misoppfattes av sykepleieren, som kan tro at pasienten ikke er oppmerksom eller er uinteressert. Pasienten kan også bruke lenger tid på å bearbeide det som blir sagt. Forsinkelsen av denne bearbeidingen gjør at mange nonverbale tegn forsvinner, eller inntrer på et senere punkt i samtalen hvor tegnet mister sin mening. Mangelfull evne til å sende og motta informasjon er et resultat av den kognitive svikten og en funksjonshemning for pasienten. Spesielt er mangel på begreper som setter ord på tanker og følelser, vanlig hos pasienter med schizofreni $(14,19)$. På grunn av disse utfordringer bør sykepleier prøve å redusere nonverbale signaler. Alle våre tre informanter forklarte hvor viktig det er å ha en god dialog med pasienten for å kunne gi trygghet. En informant forklarte det slik: «Jeg tenker det er viktig å ta seg tid til å sette seg ned og snakke med pasienten. Høre hva han har å si, eller bare lytte, egentlig. For å oppnå en god dialog». Ethvert møte med pasienten bør innebære at sykepleier er imøtekommende, viser respekt, ansvarlighet og tillit. Dette gjør man ikke bare med ord, men som vår informant beskriver, også med kroppsspråk og framferd som harmonerer med det som verbalt sies og uttrykkes med stemmens klang (15).

\section{Usammenhengene tale}

I en psykotisk fase av sykdommen kan pasientens språk være bisart ved at språket kan fremstå som en ordsalat, ha usammenhengende tale, egenkonstruerte ord eller inneholde oppdiktning (14). Dette vil vanskeliggjøre god kommunikasjon. Sykepleierne opplevde det som spesielt utfordrende å forholde seg til de psykotiske symptomene, da dette kom i tillegg til den somatiske sykdommen. Sykepleierne i vår studie var mest oppmerksomme på pasientens positive symptomer, i motsetning til å rette oppmerksomhet mot de negative symptomene. Selv om pasienter har en schizofrenidiagnose er det viktig å vite at langt fra alle pasienter vil fremstå som psykotiske. Når vi vet at de negative symptomene er vel så plagsomme for pasienten, er det av stor betydning at sykepleier har en viss kunnskap om disse symptomene. Vi tenker at en pasient med schizofreni vil trenge en rolig og trygg sykepleier, som kan gi tilrettelagt informasjon og vet å ta seg tid til å bli kjent med det unike i mennesket (6).

\section{Kroppsspråk}

Sykepleierens grunnleggende intensjoner og forståelse av den andre vil alltid oppfattes av pasienten. Hvis hun har fordommer, føler redsel eller avsky for pasienten vil dette formidles (6). Pasienter med schizofreni viser stor følsomhet og påvirkes av negativt kroppsspråk, tonefall og utsagn. Om sykepleier er bevisst på dette, vil det kunne trygge pasienten å gi positiv oppmerksomhet og anerkjennelse. Utstråler hun derimot negative holdninger og kommer med lite gjennomtenkte utsagn, kan dette medvirke til en forverret psykisk tilstand (4). Ved en travel medisinsk avdeling krever dette at sykepleier er bevisst på faren for inkongruens, det vil si at kroppsspråket ikke samsvarer med det verbale. Sykepleier kan på forhånd forberede seg på denne inkongruensen hvis hun gjør seg kjent med egne holdninger og følelser. Klarer hun dette, vil hun bli tryggere i situasjonen (16).

\section{Humor}

En av våre informanter hadde god erfaring med å bruke humor i møte med pasientene. Hun refererte til et møte med en schizofren pasient på avdelingen som flere av hennes kollegaer viste frykt for. Hun oppnådde en god relasjon til pasienten slik at hun følte det som en styrke å bruke humor. Humor kan løse opp i følelser som er vanskelige å forholde seg til. Sykepleier må være bevisst på at hver enkelt pasients grenser varierer, med tanke på hva man kan spøke med. Derimot kan humor være en gevinst, og bidra til å bygge sterke bånd og gi ytterligere nærhet $\mathrm{i}$ relasjonen. Dette fordrer at det allerede foreligger en god kontakt mellom sykepleier og pasient. Vi kan tenke oss at sykepleieren har klart å opprette et menneske-til-menneske-forhold til 
denne pasienten. Hun er i stand til å bruke seg selv terapeutisk, og for at hun skal klare dette, er det en forutsetning at hun er trygg i relasjonen (6). Vi tenker dette belyser hvor viktig det er at sykepleier klarer å møte pasienten uten fordommer.

\section{Kompetanse}

Sammenhengen mellom vitenskapelig kunnskap og den praktiske sykepleieutøvelsen, kommer til uttrykk gjennom den personlige kompetansen. I personlig kompetanse inngår intuisjon, erfaring og refleksjon. Vi tenker at refleksjon henger sammen med kritisk tenkning, som er viktig for at ikke sykepleiefaget blir utøvd på grunnlag av rein vanetenkning (17). Når sykepleieren reflekterer over sin praksis, tvinges hun til å bruke nye sider ved sin personlige kompetanse i møte med pasienten. For sykepleiere i somatikken, som ofte er usikre i møte med pasienter med en schizofrenidiagnose, kan refleksjon over egen praksis være til hjelp. Sykepleieren har både sin kunnskap, erfaring, intuisjon og evne til å tenke kritisk. Når hun er usikker og opplever utrygghet og redsel i møte med noe fremmed og ukjent, kan det by på utfordringer for sykepleieren. I likhet med å reflektere over sin praksis, bør sykepleier også reflektere over sine reaksjoner i ulike relasjonelle situasjoner. Vi ser på dette som nødvendig for å kunne bruke seg selv terapeutisk $(6,17,18)$.

\section{Diskusjon}

Sykepleier vil møte mennesker med psykiske lidelser over alt. Uansett i hvilken kontekst hun møter pasienten må hun forholde seg til mennesket og hans lidelse, og samtidig forholde seg til egne reaksjoner. Som sykepleier skal man ideelt sett kunne stå i situasjonen og være tillitvekkende uten å trekke seg unna. Hun må kjenne på ubehaget ved ikke å oppnå blikkontakt, få lite respons eller å bli utsatt for verbal eller fysisk utagering. Utfordringen i å skape en god relasjon kan oppleves som spesielt stor når den synlige og observerbare atferden til den andre føles fremmed og ukjent. Fagpersonen må våge å stå i relasjonen med nærhet og nærvær. Dette arbeidet krever årvåkenhet både i forhold til seg selv og pasienten (18). En av våre informanter forklarte hvor viktig det er å tørre å stå i situasjonen, selv om den oppleves som vanskelig. Hun har videreutdannelse i ledelse og mener at dette, i tillegg til lang klinisk erfaring, er med på å trygge henne som sykepleier i utfordrende pasientsituasjoner.

\section{Eksperthjelp}

Sykepleierne som deltok i vårt prosjekt hadde lite eller ingen kunnskap om schizofreni. Samtlige uttalte at de kun hadde grunnutdannelsen å støtte seg til i møtet med pasientgruppen, og savnet opplæring. En av dem sa hun var usikker i møte med psykisk syke. Alle mente de trengte mer kunnskap innen psykiatri. Ved flere sykehus har det av den grunn blitt opprettet et team bestående av fagfolk innen psykiatri som bistår sykepleiere på somatiske sykehus. Dette psykiatriske konsultasjonsteamet kan sette i gang viktige tiltak for pasientens psykiske tilstand, spesielt for pasienter som trenger lengre innleggelser $(19,15)$. Ved det sykehuset vi foretok intervjuer benyttet de seg av et ambulerende tverrfaglig team ved sykehusets Distriktspsykiatriske Senter (DPS). Teamet er fleksibelt og kan utføre konsultasjoner på forskjellige steder. De hadde også direkte kontakt med den psykiatriske klinikken. De fortalte om ulike typer bistand fra psykiatrien. Dette kunne være veiledning over telefon, eller at personalet fra den psykiatriske posten fulgte pasienten til den medisinske avdelingen. To av dem forklarte at de opplevde det som trygt med oppfølging og veiledning giennom hele oppholdet, og at dette viste seg å være positivt for både pasienter og sykepleiere. På en annen side må man være oppmerksom på at det er en viss fare for at sykepleier fokuserer på konsultasjonsteamet i stedet for på pasienten, og at pasienten får flere å forholde seg til. I tillegg kan det være en utfordring om det blir satt i gang tiltak som det ikke er rom og tid for å følge opp. En informant forklarte at sykepleierne kunne bruke fagutviklingssykepleieren på avdelingen som ressurs hvis det var noe de var usikre på. En annen sa at sykepleierne i avdelingen utveksler kunnskap og erfaringer med hverandre. Vi ser det som positivt at sykepleierne rådfører seg med hverandre, men mener det optimale er at sykepleieren tilegner seg kunnskap gjennom forskning og faglitteratur, eller at de tar kontakt med ekstern ekspertise.

\section{Konklusjon}

Vi har her fordypet oss i hvordan sykepleier kan ivareta en pasient med schizofreni i en somatisk sykehusavdeling. Vi ser at det er avstand mellom den ideelle ivaretakelsen og hvordan det foregår i praksis. Det er avgjørende å oppnå et menneske-til-menneske-forhold med pasienten, for at sykepleier og pasient med schizofreni skal bli trygge i relasjonen. Vi så at det kan være vanskelig for sykepleier å oppnå et menneske- til-menneske-forhold på grunn av forutinntatte oppfatninger som fører til blant annet usikkerhet, redsel og negative holdninger. Vi mener å se en sammenheng mellom økt kunnskap og gode holdninger. Redsel og usikkerhet medfører at sykepleierne fokuserer på det de ikke kan framfor det de faktisk kan. Det viser seg at sykepleierne selv mener de har lite kunnskap om psykiske lidelser generelt, og at de ønsker økt kunnskap om dette. Knapphet på tid og ressurser var en av mange utfordringer. Dette førte blant annet til nedprioritering av tiltak for å ivareta pasienten. Dette er noe vi har lagt lite vekt på her, men vi ser at det kan være behov for å studere hvordan dette påvirker ivaretakelsen av pasienten. IIII

\section{LITTERATUR}

1. Henriksen J, Vetlesen AJ. Nærhet og distanse. Grunnlag, verdier og etiske teorier i arbeid med mennesker. (3. utg.). Oslo: Gyldendal Akademisk, 2006.

2. Arvaniti A, Samakouri M, Kalamara E, Bochtsou V, Bikos C, Livaditis M. Health Arvaniti A, Samakouri M, Kalamara E, Bochtsou V, Bikos C, Livaditis M. Health service staff's attitudes towards patients with

3. Aarre TF, Bugge P, Juklestad SI. Psykiatri for helsefag. Bergen: Fagbokforlaget, 2009.

4. Jordahl H, Repål A. Mestring av psykoser. Psykososiale tiltak for pasient, pårørende og nærmiljø. (Rev. utg.). Bergen: Fagbokforlaget, 2009.

. Zolnierek CD. Non-psychiatric hospitalization of people with mental illness: systematic review. Journal of advanced nursing 2009; 65(8): 1570-83. doi: $10.1111 /$ /.1365-2648.200905044.x

6. Travelbee J. Mellommenneskelige forhold i sykepleie. Oslo: Gyldendal Akademisk, 2001.

7. Reed F, Fitzgerald $L$. The mixed attitudes of nurse's to caring for people with mental illness in a rural general hospital. International Journal of Mental Health Nursing 2005; 14(4): 249-57.

8. Peitl MV, Peitl V, Pavlovic, E, Proloscic J, Petric D. Stigmatization of patients suffering from schizophrenia. (Manus tilsendt fra forfatter). 2011http:// www.ncbi.nlm.nih.gov/pubmed/22220422

9. Hummelvoll JK. HELT - ikke stykkevis og delt. Psykiatrisk sykepleie og psykisk helse. (6. utg.). Oslo: Gyldendal Akademisk, 2004.

10. Strand L. Fra kaos mot samling, mestring og helhet - Psykiatrisk sykepleie til psykotiske pasienter. Oslo: Gyldendal Akademisk, 1990.

Kristoffersen NJ, Nordtvedt F, Skaug EA. Grunnleggende sykepleie, bind 1 . Oslo: Gyldendal Akademisk, 2005

12. Bjørk IT, Helseth S, Nortvedt F. Møte mellom pasient og sykepleier. Oslo: Bjørk IT, Helseth S, Nortvedt
Gyldendal Akademisk, 2002

13. Docherty NM. Cognitive Impairments and Disordered Speech in

Schizophrenia: Thought Disorder, Disorganization, and communication Failure. Journal of Abnormal Psychology. 2005; 114(2): 269-278. doi: 10.1037/0021843X.114.2.269

14. Krogh G. Begreper i psykiatrisk sykepleie - sykepleiediagnoser, ønsket pasientstatus og sykepleieintervensjoner. (2.utg.). Bergen: Fagbokforlaget, 2005.

15. Karoliussen M. Sykepleie - tradisjon og forandring. En humanøkologisk tilnærming. Oslo: Gyldendal Akademisk, 2002.

Eide H, Eide T. Kommunikasjon i relasjoner. Samhandling, konfliktløsning, etikk. (2.utg.). Oslo: Gyldendal Akademisk, 2009.

17. Kirkevold M. Vitenskap for praksis? (2.utg.). Oslo: Gyldendal Akademisk, 2002.

18. Haugsgjerd S, Jensen P, Karlsson B, Løkke JA Perspektiver på psykisk lidelse - å forstå, beskrive og behandle. (3.utg.) Oslo: Gyldendal Akademisk, 2009. 19. Sharrock J, Grigg M, Happell B, Keeble-Devlin B, Jennings S. The mental health nurse: a valuable addition to the consultation-liaison team. Internahealth nurse: a valuable addition to the consultation-liaison team. Interna-
tional Journal of Mental Health Nursing 2006; 15(1): 35-43. doi: 10.1111/.1.14470349.2006.00393.x

Fagartikler kan sendes til torhild.apall@sykepleien.no 